\title{
A Case of Unusual Juvenile Xanthogranuloma on the Subungual Area
}

\author{
Chan Seong Park, Dong-Youn Lee, Jae Ho Lee, Youngkyoung Lim, Ji-Hye Park, Jong Hee Lee, \\ Joo-Heung Lee, Jun-Mo Yang
}

Department of Dermatology, Samsung Medical Center, Sungkyunkwan University School of Medicine, Seoul, Korea

Dear Editor:

Juvenile xanthogranuloma (JXG) is a benign histiocytic proliferative disorder of skin, which is characterized by solitary or multiple yellow-red nodules. JXG usually occurs in infancy or early childhood. The pathophysiology of JXG is not yet understood, although it is thought to repre- sent a histiocytic granulomatous reaction. Lesions mostly present on the head, neck, and trunk, however, the involvement of the distal extremities such as fingers and toes is very rare; only 6 cases of JXG involving a nail have been reported in the English and Korean literature. Herein, we report on an unusual clinical presentation of JXG de-
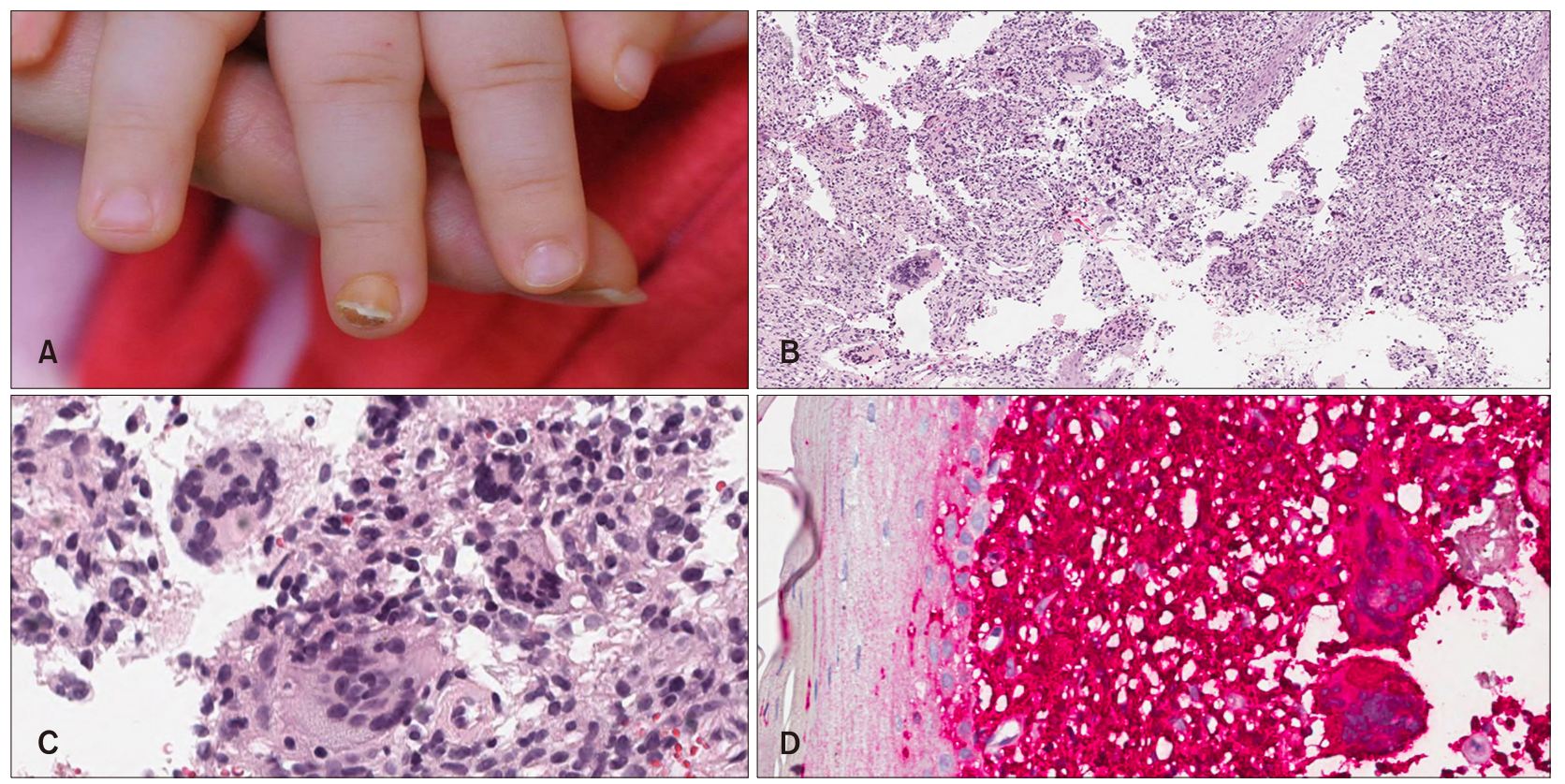

Fig. 1. (A) Yellow firm nodule under the nail right 3rd finger nail plate. (B) Dense intradermal histiocytic infiltrates and a number of giant cells $(H \& E, \times 200)$. (C) Foreign body giant cells with haphazard nuclear arrangement were mainly observed (H\&E, $\times 400)$. (D) All of histiocytes were positive for CD163 (CD163, $\times 400)$.

\section{Received April 12, 2017, Revised March 26, 2018, Accepted for publication March 27, 2018}

Corresponding author: Dong-Youn Lee, Department of Dermatology, Samsung Medical Center, Sungkyunkwan University School of Medicine, 81 Irwon-ro, Gangnam-gu, Seoul 06351, Korea. Tel: 82-2-3410-3543, Fax: 82-2-3410-3869, E-mail: dylee@skku.edu ORCID: https://orcid.org/0000-0003-0765-9812

This is an Open Access article distributed under the terms of the Creative Commons Attribution Non-Commercial License (http://creativecommons.org/ licenses/by-nc/4.0) which permits unrestricted non-commercial use, distribution, and reproduction in any medium, provided the original work is properly cited.

Copyright (C) The Korean Dermatological Association and The Korean Society for Investigative Dermatology 
veloping below the finger nail

JXG is a benign histiocytic proliferative disorder of skin, which is characterized by solitary or multiple yellow-red nodules. JXG usually occurs in infancy or early childhood. Lesions mostly present on the head, neck, and trunk; however, the involvement of the distal extremities such as fingers and toes is very rare; only 6 cases of JXG involving a nail have been reported in the English and Korean literature $^{1-5}$. Herein, we report on an unusual clinical presentation of JXG developing below the finger nail.

A healthy 7-month-old girl presented with 4 months history of a yellow discolored nail deformity in the right $3 \mathrm{rd}$ finger. There was no remarkable past or family history. On physical examination, the yellow firm nodule was seen under the nail plate and a yellowish plaque was also observed on the neck (Fig. 1A). We received the patient's consent form about publishing all photographic materials. There was a yellowish patch on the neck on physical examination. Excisional biopsy was done to rule out viral wart or corn.

Pathologic finding reveal showed dense intradermal histiocytic infiltrates which contained foamy cell (Fig. 1B). Many giant cells were observed, which mainly comprised of foreign body giant cells with haphazard nuclear arrangement and focal Langhans type giant cells with horseshoe-shape nuclear arrangement (Fig. 1C). Differential diagnosis included non-Langerhans cell histiocytosis such as JXG and soft tissue mesenchymal tumors with rich giant cells such as giant cell tumor of soft tissue. All histiocytes was positive for CD163 (Fig. 1D). There were scattered lymphocytes and eosinophils and were not chondrocytes and osteocytes. Based on histopathologic findings, age and morphology, it was diagnosed with JXG. When she came back 15 months after the skin biopsy, there was no residual tumor.

JXG is the most common form of non-Langerhans cell histiocytosis and is considered a benign histiocytic proliferation. JXG usually present on the head, neck, and trunk, however, the involvement of fingers and toes is rare and few cases were reported. Only 6 cases of JXG involving nail unit have reported in the English and Korean literature; these cases are summarized in Table $1^{1-5}$.

Four cases $^{2-5}$ were associated with a finger nail and two cases $^{1,5}$ involved a toe nail. Two cases ${ }^{4,5}$ involved proximal nail fold and other cases ${ }^{1-3,5}$ occurred in subungual area. JXG regressed spontaneously in two cases ${ }^{2,5}$. Tumor removal was done in three cases ${ }^{1,2,5}$; permanent nail dystrophy was observed in one case ${ }^{1}$ and no recurrence was observed in another case $\mathrm{e}^{5}$.

JXG associated with nail unit is often misdiagnosed clinically as a common wart, glomus tumor, pyogenic granuloma, keratoacanthoma, or as corn ${ }^{5}$. However, these diagnoses can be distinguished from JXG by the characteristic histopathologic findings; dense intradermal histiocytic infiltrates which contained foamy cells and giant cells. In some cases, immunohistochemistry such as factor XIIla and CD163 could be helpful in differentiating other fibrohistiocytic tumors.

Table 1. Review of the cases of juvenile xanthogranuloma involving the nail reported in the English and Korean language published work

\begin{tabular}{|c|c|c|c|c|c|c|c|}
\hline Case & Sex/age & Onset & Location & Associated features & Treatment & Outcome & Reference no. \\
\hline 1 & $\mathrm{M} / 3 \mathrm{yr}$ & $\begin{array}{l}\text { Before } \\
1.5 \text { years }\end{array}$ & $\begin{array}{l}\text { Left secondtoe } \\
\text { beneath a toenail }\end{array}$ & $\begin{array}{l}\text { The whole nail bed including } \\
\text { the matrix was involved }\end{array}$ & Tumor removal & $\begin{array}{l}\text { Permanent nail } \\
\text { dystrophy after } \\
7 \text { months }\end{array}$ & 1 \\
\hline 2 & $\mathrm{M} / 2.5 \mathrm{yr}$ & Unknown & $\begin{array}{l}\text { Right index finger } \\
\text { beneath a fingernail }\end{array}$ & $\begin{array}{l}\text { Lifting up and dystrophic } \\
\text { nail by tumor }\end{array}$ & $\begin{array}{l}\text { Tumor removal } \\
\text { after nail avulsion }\end{array}$ & No $F / U$ & 2 \\
\hline 3 & M18 mo & $\begin{array}{l}\text { Before } \\
7 \text { months }\end{array}$ & $\begin{array}{l}\text { Proximal nail fold of } \\
\text { right thumbnail }\end{array}$ & $\begin{array}{l}\text { Severe depressed nail plate } \\
\text { and hyperkeratotic cuticle }\end{array}$ & None & $\begin{array}{l}\text { The lesion } \\
\text { completely } \\
\text { disappeared }\end{array}$ & 3 \\
\hline 4 & $\mathrm{~F} / 7 \mathrm{mo}$ & $\begin{array}{l}\text { Before } \\
5 \text { months }\end{array}$ & $\begin{array}{l}\text { Proximal nail fold of } \\
\text { right little finger }\end{array}$ & $\begin{array}{l}\text { Partial invasiontoward the } \\
\text { nail plate }\end{array}$ & None & $\begin{array}{l}\text { The lesionremain } \\
\text { 5-month- F/U }\end{array}$ & 4 \\
\hline 5 & $\mathrm{~F} / 24 \mathrm{mo}$ & $\begin{array}{l}\text { Before } \\
1 \text { month }\end{array}$ & $\begin{array}{l}\text { Left Firsttoe } \\
\text { beneatha toenail }\end{array}$ & $\begin{array}{l}\text { The whole nail bed including } \\
\text { the matrix was involved } \\
\text { and nail lost }\end{array}$ & None & $\begin{array}{l}\text { The lesion } \\
\text { completely } \\
\text { disappeared }\end{array}$ & 5 \\
\hline 6 & $\mathrm{~F} / 21 \mathrm{yr}$ & $\begin{array}{l}\text { Before } \\
6 \text { months }\end{array}$ & $\begin{array}{l}\text { Left thumb finger } \\
\text { beneatha umbnail }\end{array}$ & Lifting up by tumor & $\begin{array}{l}\text { Tumor removal } \\
\text { after nail avulsion }\end{array}$ & No recurrence & 5 \\
\hline 7 & $\mathrm{~F} / 7 \mathrm{mo}$ & $\begin{array}{l}\text { Before } \\
4 \text { months }\end{array}$ & $\begin{array}{l}\text { Right third finger } \\
\text { beneath a fingernail }\end{array}$ & $\begin{array}{l}\text { Lifting up and dystrophic } \\
\text { nail by tumor }\end{array}$ & $\begin{array}{l}\text { Tumor removal } \\
\text { without nail } \\
\text { avulsion }\end{array}$ & No recurrence & This case \\
\hline
\end{tabular}

M: male, F: female, F/U: follow-up. 
In conclusion, JXG can present in unusual sites associated with nail unit and can be misdiagnosed such as common wart and other diseases. So, it is necessary to check histopathology not to misdiagnose and mistreat. This case illustrates a rare JXG of the right 3rd finger nail bed in a 7-month-old girl which was diagnosed based on its characteristic histopathologic findings.

\section{CONFLICTS OF INTEREST}

The authors have nothing to disclose.

\section{ORCID}

Chan Seong Park, https://orcid.org/0000-0001-5809-0561

Dong-Youn Lee, https://orcid.org/0000-0003-0765-9812

Jae Ho Lee, https://orcid.org/0000-0002-5810-4852

Youngkyoung Lim, https://orcid.org/0000-0002-6409-2704

Ji-Hye Park, https://orcid.org/0000-0002-6699-5202

Jong Hee Lee, https://orcid.org/0000-0001-8536-1179
Joo-Heung Lee, https://orcid.org/0000-0002-1121-2055

Jun-Mo Yang, https://orcid.org/0000-0003-0656-8046

\section{REFERENCES}

1. Frumkin A, Roytman $M$, Johnson SF. Juvenile xanthogranuloma underneath a toenail. Cutis 1987;40:244-245.

2. Chang $P$, Baran R, Villanueva C, Samayoa M, Perrin C. Juvenile xanthogranuloma beneath a fingernail. Cutis 1996; 58:173-174.

3. Piraccini BM, Fanti PA, Iorizzo M, Tosti A. Juvenile xanthogranuloma of the proximal nail fold. Pediatr Dermatol 2003;20:307-308.

4. Kim EJ, Kim MY, Kim HO, Park YM. Juvenile xanthogranuloma of the finger: an unusual localization. J Dermatol 2007;34:590-592.

5. Kim JK, Kim B, Won CH, Chang SE, Lee MW, Choi JH, et al. Subungual juvenile xanthogranuloma. Korean J Dermatol 2012;50:354-357. 